\title{
Education and Local Language: The Vitality of Tae' Language in School
}

\author{
Rusdiansyah \\ LPDP (Indonesia Endowment Fund for Education) Awardee \\ Magister in Linguistics, Indonesia University of Education \\ rusdiansyah_amir@yahoo.com
}

\begin{abstract}
The aim of this study is to describe that school is one of big effects in influencing local language shift (Tae' language) and to see the vitality of Tae' language in school environment. As the heritage of nation, local language now has faced a shift and if it happens continuously, local language will face an extinction. Education that should be the one of main factors in preserving and maintaining local language has not shown its role yet in preserving and mainta ining local language for students as the successor in maintaining local language. Even, education nowadays has been one of the factors that trigger a language shift itself. The methodology used in this study is descriptive qualitative, where the researcher uses the questionnaire to take the data. The result of the research shows that it is indeed that school gives the impact towards language shift because at school, the rules of using national language (Indonesian) in learning process is the obligation that must be followed by the students and the teachers. It can be inferred that the rules give the impact toward the language shift itselfand even, it becomes a trigger of Tae' language extinction.
\end{abstract}

Keywords: education, local language, language shift.

\section{Introduction}

Education as a part of language society has a big impact towards a language existence. By including local language in school curriculum and using local language in school activities can be the way in preserving and maintaining local language at school.

In education nowadays, Indonesian language is used as a main language where students and teachers are forced to communicate with. In 1945 Indonesian constitution, it is said that Indonesian language is (the) national and formal language which must be used as an administration and governmental language, it also must be used in formal situations including educational activities. Those factors, can be inferred as the trigger of language shift that influence the existence of Tae' language.

The obligation to use Indonesian in school activities affects the use of local language in family environment. Parents tend to avoid the use of local language at home in communicating with their children, even some of them never use the local language at all. Because they think that teaching local language to their children can give the impact towards language use of their children in school environment.

Indonesian is the major language in Indonesia. A major language becomes a main language that is used by people, and it shifts the existence of minor language, and the minor language will extinct. (Fishman:2001)[1].

In Jumharia Djamereng researched (2016) about the effect of attitude and parents' role towards Luwu language shift on children in Luwu's people, it showed that the local language has been decreasing because their parents have never taught their kids how to use local language, in this case 'Tae' language[2]. If this problem happens continuously, it will trigger the local language extinction, in which it is the identity and the heritage of Indonesian people.

This research is an initial project, and it still can be conducted later. The researcher only took one school as object of this research. The method used in this research was descriptive qualitative method. The sample used was students and teachers at one Junior High School in Luwu, South Sulawesi province. The total sample of 20 Junior High School students and 5 teachers which Tae' language as their mother tongue, because Luwu district has dominated native speakers of Tae' language. Data collection method used was questionnaires. The questionnaire is a research method that allows the respondents to answer and express his views on a particular issue. 


\section{Theoritical Framework}

\subsection{Maintenance and language shift}

Language maintenance is a language attitude from the society or community of language speaker to keep using their own language in daily communication. However, if a community has chosen another language to be used in communication because of many reason, then language shift will happen.

In language maintenance, language speaker usually relates to the use of two language or more. Therefore, speakers' attitude or people become the one who are responsible to choose which language that is going be used. Whether they are going to use major or minor language. And if it happens, the language shift will occur and it cannot be avoided. In maintaining minority language, Fishman (1991) believe in reversing language shift. Minority language can be used in higher level of education, lower education, occupational, governmental, and media effort. Minority language also should become literacy in home, school and other community and minority language should be used in childbearing age[3].

There are so many factors that can cause language shift and language maintenance. First is immigration, Chaer $(2004 ; 142)$ said that language shift is the problem of language used by community and society that happens because of the movement of one community to another place or language shift occur because one community is influenced by people who come to their community [4].

Second, language shift is also caused by economic factor. According to Sumarsono and Partana (2002:237) industrialization is one of the economic factor. Economic development sometimes can raise a language position to be more valuable in economic aspect. Third, language shift occurs because of school environment, sometimes school is considered as the factor which cause the mother language shift. It is because students at school are taught to use national language and even foreign language[5]. Parents, never teach their children how to use local language and they think their children will not understand the subjects at school if they learn local language because school uses only national language. Children know how to understand local language but they do not know how to interact using local language.

Some linguists said that there are two issues of language extinction. They are related to "language murder and language suicide". Language murder happens if government or language institution oblige not to use minor language. Meanwhile, language suicide happens when the speakers of the language do not want to use the language anymore, they are not proud of their language anymore and they like to use another language which is well-known and more valuable in economic and politic aspects (Diane Nelson : 2008) [6].

According to Dorian (in E. Holloway C : 1997), language extinction happens because language can be resistant of language competition[7]. Language is not really dead because language is not creatures or human being, but language just disappears and it is kicked by a dominant language that is more frequently used by people[8].

\subsection{Luwu Language (Tae' language)}

Luwu language or language Tae' is a mother tongue language used by communities in Tana Luwu. Tae ' language is the lingua franca because it is used by most residents of Tana Luwu as a daily language. There are four Luwu districts where Tae' language is used in daily communication, they are Luwu, North Luwu, east Luwu, and Palopo city.

Tae 'language is used as the language of communication of locals, from the Southern border, Buriko (Wajo)

until Malili East Luwu, and Tana Toraja and Massenrempulu. Tae' language is a language family that consists of 12 tribal languages (dialects) used by the people who are in the region of Tana Luwu. Tana Luwu is an area was the former Kedatuan (Kingdom). Ancient Kedatuan Luwu was spread into four districts, they are Luwu, East Luwu, North Luwu, Kota Palopo, Siwa (Wajo), Kolaka, Lasusua (Northern Sulawesi). But now, Tana Luwu it only consisted of Luwu, North Luwu, East Luwu, and Kota Palopo.

\subsection{Language attitude}

There are several definitions of the attitude of language according to the experts. According to Kridalaksana (2001) the attitude of the language is a mental position or feeling toward their own language or 
others language[9]. The language attitude of the speaker will manifest themselves in the form of a sense of pride or ridicule, reject or simultaneously accept a specific language or the community that use specific language, both the language mastered by every individual as well as by members of the society. This attitude of language indicates a person's attitude about their language, whether they have a positive attitude that will affect the survival of the language or even negative attitude toward the local language that will decrease the use of local languages.

However, if the attitude of language is associated in the context of education, the attitude of language will be influenced by the use of the existing language in school. Language pride of using local language will disappear when they use their majority language. Otherwise, pride or a positive attitude will emerge only when the majority of them use the same language. There are several characteristics of language attitude which formulated by Garvin and Mathiot (1968) as it describes as follows:

- Language loyalty that encourages people retains their language, and if necessary it will prevent the influence of other languages.

- Language pride that encourages people to develop their language and use it as a symbol of identity and unity of the society.

- Awareness of language norms that encourage people to use language carefully and politely; and it is a huge factor that influence language use activities[10].

From that explanation, it can be concluded that the language attitude of people is very influential in the maintenance or the extinction of a local language. Due to survive or extinct of the language starts from the attitude toward language and it will lead to activities both activities using the language or another language that is considered better. The attitude of language can be seen through the frequency of use of language and also about his mastery of the language itself.

\section{Findings and discussions}

Based on Indonesian Constitution Number 24 of 2009 article 29 verse 1 about National Flag, Language, and the Symbol of the state and also national anthem, stated that the Indonesian must be use as the language instruction in the national education. It is also stated in Indonesia Constitution Number 20 of 2003 article 33 verse 1 about the national education system, Indonesian as a national language becomes the language of instruction in national education. Other than that it is stipulated in Government Regulation of the Republic of Indonesia number 57 of 2014 article 5 (b) stated that Indonesian as the national language official functions as the the language of instruction of education. By reason of Constitutions and other regulations that require the use of Indonesian as a language instruction in education, the schools implemented that rule. Therefore Indonesian schools use the Indonesian and not using local languages as language instruction in schools.

However, if it is observed closely, the real education laws which is regulated by constitutions and other regulations do not forbid the use of local languages as languages instruction. In Indonesian Constitution Number 20 of 2003 about the national education system article 33 verse 2 it is stated that the regional languages can be used as the language instruction in the early stages of education if it is necessary to deliver particular knowledge and / or skills. In addition, UNESCO also said that the language instruction in education can use the local language. The learning process at an early stage should use the mother tongue[11]. Institutional like education, mass media and government become one of elements to increase the vitality of language (M. Meyerhoff: 2006) [12].

According to Mahsum (in Republika e-Paper) the results of research by Global Education Monitoring that was designated by UNESCO said that there were 40 percent of students of the world's population join learning process in schools using less well-understood language or it's not their mother tongue. As a result, students cannot effectively absorb the knowledge. This condition let them to use their mother tongue as the language of instruction at the starting level in the world of education. The use of mother tongue in the learning process can improve the students' achievement and to protect the mother tongue from the extinction threat[13].

According to James Cummins (1996) the students will learn more effectively in school with the use of their first language or mother tongue, but many parents are not aware of it. Parents just teach the language that is considered more prestigious to their children[14]. But in reality, schools, especially in South Sulawesi, prefer to use Indonesia rather than use Tae' as the in instructional process. It is because they intent to follow the Indonesian regulations. They use language instruction based on the constitutions and other rules that requires the 
use of the national language in this case Indonesian as the language of instruction in education. Local language could be introduced as a medium of instruction in school (Fishman:1968)[15].

The use of Indonesian in teacher and students interation deposed the use of Tae' language as the daily language of Luwu society. As a result, it decreased the number of Tae' native speaker because Indonesian is dominantly used. The process of teaching and learning in school in all subjects uses Indonesian as a language instruction. Teachers provide a good example in the Indonesian language. However, they never give model of using Tae' language to students, therefore the students did not have exposure about Tae' language and it affected to the decreasing of Tae' usage. Even Tae 'language no longer used in the learning process at school.

From the research conducted at one of the Junior High School in Luwu, it was generated a strong enough data where the use of language Tae' in school environment was rarely used, even it affected the use of language Tae' in family environment and other social environment which began to fade away. It was identified as the one of the signs of Tae' language shift in society. Based on research on Tae' language acquisition then it was obtained some results as follows:

TABLE 1: Student's Language use level

\begin{tabular}{lccccc}
\hline \hline Language Use & & Very & Strong & Weak & Very \\
Strong & & & \\
Tae' Language & Speaking & $60 \%$ & $26.67 \%$ & $13.33 \%$ & - \\
& Reading & $40 \%$ & $33.33 \%$ & $20 \%$ & $6.67 \%$ \\
& Writing & $46.67 \%$ & $33.33 \%$ & $13.33 \%$ & $6.67 \%$ \\
& Understan & $20 \%$ & $40 \%$ & $40 \%$ & - \\
ding & Speaking & $89.47 \%$ & $10.53 \%$ & - & - \\
& Reading & $73.68 \%$ & $15.79 \%$ & $10.53 \%$ & - \\
& Writing & $68.42 \%$ & $15.79 \%$ & $15.79 \%$ & - \\
& Understan & $52.63 \%$ & $26.32 \%$ & $21.05 \%$ & - \\
\hline \hline
\end{tabular}

From the table above it can be seen that the students have more mastery in Tae' language speaking, but the students were still lack of the other aspects such as reading, writing, and even it was still difficult to understand what people were saying. Furthermore, below is the results of research on the use of language at school environment.

TABLE 2: Language use at school

\begin{tabular}{lccc}
\hline \hline Language use & Indonesian & Tae' & $\begin{array}{l}\text { Mixing between Tae' and } \\
\text { Indonesian }\end{array}$ \\
\hline $\begin{array}{l}\text { Talking to the teachers in the } \\
\text { classroom }\end{array}$ & $100 \%$ & - & - \\
$\begin{array}{l}\text { Talking to the teachers out of } \\
\text { classroom }\end{array}$ & $100 \%$ & - & - \\
$\begin{array}{l}\text { Talking to friends in the } \\
\text { classroom }\end{array}$ & $65 \%$ & $10 \%$ & $25 \%$ \\
$\begin{array}{l}\text { Talking to friends out of } \\
\text { classroom }\end{array}$ & $50 \%$ & $10 \%$ & $40 \%$ \\
\begin{tabular}{l} 
When playing with friends \\
\hline \hline
\end{tabular} & $35 \%$ & $40 \%$ & $25 \%$ \\
\hline
\end{tabular}

The data above explains that the use of Tae' language in school environment is considered very poor or low. Where $100 \%$ of students used Indonesian in the teaching and learning process or for that matter when they were talking to the teachers. While the use of local language at school environment was only used when they talked and played with friends, but it still in very few portion. Below is the result of the use of language in the home, neighbors, and other social environments: 
TABLE 3: Language use at home, neighborhood and social environment

\begin{tabular}{lccc}
\hline \hline Language use & Indonesian & Tae' & $\begin{array}{c}\text { Mixing between Tae and } \\
\text { Indonesian }\end{array}$ \\
\hline Talking to father & $45 \%$ & $5 \%$ & $50 \%$ \\
Talking to mother & $45 \%$ & $5 \%$ & $50 \%$ \\
Talking to siblings & $45 \%$ & $10 \%$ & $45 \%$ \\
Talking to grandpa/grandma & $35 \%$ & $15 \%$ & $50 \%$ \\
Language use of anger & $35 \%$ & $40 \%$ & $25 \%$ \\
expression & $100 \%$ & - & - \\
Texting with friends & $100 \%$ & - & - \\
Texting with family & $85 \%$ & $15 \%$ & - \\
At market & $100 \%$ & - & - \\
In public transportation & & & \\
\hline \hline
\end{tabular}

From data on the use of languages in the family and other social environments it can be concluded that the loyalty of using local language is very low. Even talk to parents, they used Tae' language as much as 5\%. This is A very poor condition about awareness of the use of Tae' language. In addition, it also found that the interference of code mixing in language use among students, the mix between Indonesian and Tae' language. And the percentage of the code-mixing can be fairly high at $45 \%$. Indonesian remained as the language most commonly used by students in a family environment and other social environment.

In addition to data about students above, it was also taken data on the level of mastery of the language by teachers. It is discussed by the following table:

TABLE 4: Teacher's language use level

\begin{tabular}{|c|c|c|c|c|c|}
\hline Language Use & & $\begin{array}{l}\text { Very } \\
\text { Strong }\end{array}$ & Strong & Weak & $\begin{array}{l}\text { Very } \\
\text { weak }\end{array}$ \\
\hline \multirow[t]{4}{*}{ Tae' language } & Speaking & $40 \%$ & $20 \%$ & $40 \%$ & - \\
\hline & Reading & $40 \%$ & $20 \%$ & $40 \%$ & - \\
\hline & Writing & $40 \%$ & - & $60 \%$ & - \\
\hline & $\begin{array}{c}\text { Understan } \\
\text { ding }\end{array}$ & $60 \%$ & - & $40 \%$ & - \\
\hline \multirow[t]{4}{*}{ Indonesian } & Speaking & $100 \%$ & - & - & - \\
\hline & Reading & $100 \%$ & - & - & - \\
\hline & Writing & $100 \%$ & - & - & - \\
\hline & $\begin{array}{c}\text { Understan } \\
\text { ding }\end{array}$ & $100 \%$ & - & - & - \\
\hline
\end{tabular}

Based on the table above it can be seen that the level of mastery of the Tae' language by teachers in terms of speaking, reading and writing it is still somewhat less. But in terms of understanding what a person says in a Tae' language it was still good enough. But the overall level of mastery was at the level of very fluently and weak. As for the Indonesian language, $100 \%$ mastery was very substandard.

Based on the research above, we can see that the use of Tae' language in school environment was very low. One thing that makes this happen because of the use of Indonesian in schools. Mastery of the Tae' language by teachers is low. as the result, teachers also cannot communicate well to the students in Tae' language. And it alsso caused by the rule that be hold of the school about using Indonesian as a language of instruction so that it affected on decresing of using Tae' language in school environment and even affected the daily life of students. The use of Tae' language has been replaced by the Indonesian.

The use of Indonesian also caused the attitudes of language in which the use of Tae' language has already decreased. The things worried by the linguist and researcher- the sign of language shift- has already appeareed, in this case is the language Tae '. Because the awarness of younger generation, the next generation and guardian of the nation identity to preserve the local language has decreased. 
The use of Tae' language is not only low in the school environment, but it affect on the social environment of these students. The students are accustomed and indoctrinated to always use the Indonesian language in everyday life. In a family environment, the use of Tae' language is still lack. Parents should communicate using mother tongue to their children in order to give them an exposure about the local language. Therefore the children wil continuously preserve their mother tongue. But in fact, they are more proud to use the Indonesian which is considered as more prestige language rather than local languages or in this case is the Tae' language.

By increasing the use of Indonesian among the community makes the use of Tae' language in daily communication is likely to be declined, triggering a shift in Tae' language it may even trigger the extinction of the language. Because the extinct of local language begins with the reducing in using local languages among children. Because children are the generation that can use the local languages in the future, but if the children are not able to use the local language, then gradually the local languages will be extinct.

\section{Conclusion}

The use of the language instruction in education has been arranged either in constitution such as the Constitution of Indonesia Number 24 of 2009 or on the Constitution of Indonesia Number 20 of 2003, and also in the Indonesian Government Regulation number 57 of 2014. Because of these rules, schools use Indonesian as a language instruction so that students also must be use Indonesian in the learning process.

The use of local languages as the language instruction at school in the learning process is not actually forbidden. But this contradicts on language use at school in Luwu district. Where Indonesian used as the language instruction in the learning process without using Tae' language as a mother tongue. According to the results of this research that students used more Indonesian at the school environment rather than Tae' language. And affecting both the use of language in a family and social environment of the students.

The use of Tae' languages as a mother tongue in education should be increased to attempt maintenance and preservation of the identity of Indonesia. Even the Tae' language should be seen as an effective medium of interaction in improving intelligence of the students in Luwu. Vitality of Tae' language can survive if Tae' language is continuesly used for a range of social functions like in education.

Education is one of the pillars in the maintenance and preservation of languages and cultures in Indonesia, including local languages. With the use of local languages as the language instruction in the learning process, will create the next generation to maintain the use of local languages which are an asset to this nation. By maitaining the use of local language in school will trigger them to use the local language in every social life. So the local language which is the identity of Indonesia can survive for the future. Indeed Indonesian as the national language should be preferred, but still the use of local languages must be preserved as the national identity.

\section{Acknowledgement}

The author would like to acknowledge and express my greatest gratitude to the Indonesia Endowment Fund for Education (LPDP) for its support of Rusdiansyah's research. And the author would also like to thank to Mr. Eri Kurniawan, M.A., Ph. D. and Mr. Dadang Sudana, M.A., Ph. D. for their assistance, advice and support during this research.

\section{References}

[1] J. Fishman, Why is it so hard to save a threatened language? Clevedon: Multilingual Matters, 2001

[2] J. Djamareng and Jufriadi, "Pengaruh Sikap dan Peran Orang Tua terhadap Pergeseran Bahasa Luwu di Kalangan Anak-anak pada Masyarakat Luwu Kota Palopo,” PALITA J. Soc. Res., vol. I, pp. 79-94, 2016.

[3] J. A. Fishman, Reversing Language Shift: Theoretical and Empirical Foundations of Assistance to Threatened Languages. Clevedon: Multilingual Matters, 1991.

[4] Chaer and L. Agustina, Sosiolinguistik Perkenalan Awal. Edisi Revisi. Jakarta: Rineka Cipta, 2004.

[5] Sumarsono and P. Partana, Sosiolinguistik. Yogyakarta: Pustaka Pelajar, 2004.

[6] V. Renaud, The Routledge Companion to Sociolinguistics, vol. 2, no. 1. 2008. 
[7] C. E. Holloway, Dialect Death: The case of Brule Spanish.Amsterdam/philadelphia: John Benjamins Publishing company, 1997.

[8] K. D. Harrison, When Languages Die. New York: Oxford University Press, Inc., 2007.

[9] https://doi.org/10.1093/acprof:oso/9780195181920.001.0001

[10] H. Kridalaksana, Kamus Linguistik. Jakarta: PT. Gramedia Pustaka Utama, 2001.

[11] P. L. Garvin and M. M, "The Urbaization of Guarani Language. Problem in Language and Culture," in Reading in Tes Sosiology of Language, Mounton. Paris: The Hague, 1968.

[12] D. Bühmann and B. Trudell, "MotherTongue Matters : as a Key to Effective Learning," Unesco, pp. 1-50, 2008.

[13] M. Meyerhoff, Introducing Sociolinguistics, I., vol. 91. New York: Tailor \& Francis e-Library, 2006.

[14] Mahsum, "Bahasa Ibu dan Pendidikan," REPUBLIKA.CO.ID | EPAPER REPUBLIKA, 2016. [Online]. Available: http://www.republika.co.id/berita/koran/opini-koran/16/03/02/o3ee0815-bahasa-ibu-dan-pendidikan. [Accessed: 09-Mar-2017].

[15] J. Cummins, Negotiating identities: Education for empowerment in a diverse society. Los Angeles: California Association for Bilingual Education, 1996.

[16] J. Fishman, Readings in the Sociology of Language. The Hague: Mouton, 1968. 